DEMOCRACY, DICTATORSHIP AND

DEVELOPMENT 


\section{Democracy, Dictatorship and Development}

Economic Development in Selected Regimes of the Third World

Georg Sørensen Associate Professor of the Institute of Political Science Aarhus University, Denmark 
ISBN 978-1-349-11317-0

ISBN 978-1-349-11315-6 (eBook)

DOI 10.1007/978-1-349-11315-6

(C) Georg Sørensen 1990

Softcover reprint of the hardcover 1st edition 1990 978-0-333-51663-8

All rights reserved. For information, write:

Scholarly and Reference Division,

St. Martin's Press, Inc., 175 Fifth Avenue,

New York, N.Y. 10010

First published in the United States of America in 1990

Library of Congress Cataloging-in-Publication Data

Sørensen, Georg, 1948-

Democracy, dictatorship and development: economic

development in selected regimes of the Third World/Georg Sørensen.

p. cm.

Includes bibliographical references.

ISBN 978-0-312-04642-2

1. Economic development-Political aspects. 2. Democracy.

3. Authoritarianism. I. Title.

HD75.S66 1990

$338.9^{\prime} 009172^{\prime} 4-\mathrm{dc} 20$

$90-30360$

CIP 
To Dieter Senghaas 


\section{Contents}

List of Tables and Figures ix

Preface xi

1 ANALYTICAL FOCUS

1.1 Introduction 1

1.2 Regimes and Development: The Arguments in Detail 2

1.3 The Basic Concepts of the Analysis 17

1.4 The Framework of the Analysis 27

1.5 Values and Ethnocentrism 31

1.6 Hypotheses and Questions for the Case-studies 32

1.7 Introduction of the Case-studies 34

2 INDIA

2.1 Legacy of the Past

2.2 Economic Development: Plans, Policies and Achievements

2.3 Democracy and Development: A Preliminary Valuation

2.4 Democracy and Development: Three Crucial Questions

2.5 Authoritarian Interlude: The 1975-1977 Emergency 69

2.6 Democracy and Development in India 73

\section{CHINA}

3.1 Legacy of the Past

3.2 Economic Development: Plans, Policies and Achievements

3.3 Socialist Authoritarianism and Development: A Preliminary Valuation

3.4 Socialist Authoritarianism and Development: Three Issues

3.5 Authoritarianism and Development in China

4.1 Legacy of the Past

4.2 Economic Development: Plans, Policies and Achievements 
viii

4.3 Authoritarianism and Development:

A Preliminary Valuation

4.4 Authoritarianism and Development in Taiwan: Three Issues

4.5 The Taiwan Case of Authoritarianism and Development

5 COSTA RICA

5.1 Legacy of the Past

5.2 Economic Development: Plans, Policies and Achievements

5.3 Democracy and Development: A Preliminary Valuation

5.4 Internal and External Forces in Costa Rican Development

5.5 Democracy and Development in Costa Rica

6 THEORETICAL IMPLICATIONS

6.1 Introduction

6.2 Democracy and Development

6.3 Authoritarianism and Development

6.4 Democracy versus Authoritarianism: Comparing Across Systems

6.5 The Relevance of the Analysis for other Third World Countries

6.6 Democracy, Dictatorship and Development

Notes

Bibliography 


\section{List of Tables and Figures}

Tables:

1.1 Hypothetical consequences of regime form for economic development performance

2.1 Changes in weight of major industrial groups in the index of industrial production, India 1956-1984

3.1 Distribution of land owned, rural China, 1930s to 1950

3.2 Distribution of gross industrial output, per cent, China 1986

3.3 Impact of land reform on distribution of land ownership, China

3.4 Per capita consumption of consumer goods, China

3.5 Rural and urban ownership of selected durables, China 1978

4.1 Agricultural development indicators, Taiwan 1952-1980 127

4.2 Shares of industrial value added, selected industries in per cent, Taiwan

4.3 Welfare in Taiwan, selected indicators

4.4 Real wages and productivity in manufacturing industry average change per annum in per cent, Taiwan 1952-1982 139

5.1 Costa Rica: Per capita income and welfare indicators 156

Figures:

1.1 Tentative classification of contemporary regimes 25

1.2 Regime form and economic development 28

1.3 Factors other than form of regime influencing economic development 


\section{Preface}

It was a visit to India in 1985 that sparked my interest in the problems which ultimately led to the writing of this book. On first impression, India is a slap in the face of well-meaning people like myself, who feel that democracy and economic development (especially the welfare dimension) ought to go hand in hand and can indeed do so, in a mutually supportive process. After the visit, much time had to be spent in getting around to ask what I thought were the right questions. Getting the questions right was difficult because several important and rather different research traditions are active in the problem area involving the relationship between regime types and economic development. This study draws on the 'political science tradition' as well as on the 'political economy of regimes tradition' as will be explained in Chapter 1 .

The book could not have been written without a lot of help from many different quarters. A visit to Berkeley and Stanford in 1986 contributed to clarifying what I actually wanted to do; talks with David Collier and Jyotirindra Das Gupta were particularly helpful. So were the comments from the participants in the Nordic Summer University's session in Iceland in August 1987, where I presented a paper with the early ideas on the book. During September and October 1988, I made a research trip to China and Taiwan in the context of this study. The information and impressions gathered there are highly important, not only for the chapters on the two countries, but also for my broader view of the issues addressed in the book. I am deeply grateful to the large number of scholars and officials in the two countries who gave me their time to explain various aspects of political and economic issues. Professor Zhang Yunling of the Chinese Academy of Social Sciences not only provided friendly support and advice, but also took the burden of arranging my whole stay in China and helped open the doors to people whom it would have been impossible to reach had I been on my own. In Taiwan, Chen Yong-Fa of the Academia Sinica freely and at very short notice took on a similar burden; Pin-Tsun Chang became a friend very quickly; he introduced me to his family and helped provide a more profound understanding of Taiwanese life. In Denmark, Olav Jull Sørensen, Keld-Erik Brødsgaard and Clemens Stubbe Østergaard 
were very helpful in the early preparations of my trip to China and Taiwan.

Research time at Aalborg University, where I have worked as an associate professor at the International Studies Program, together with a grant from the Council for Development Research provided the economic basis for the study. I am also grateful for financial support from Aalborg University's Research Council and from the Nordic Cooperation Committee for International Politics.

Comments from a number of students, friends and colleagues helped turn the manuscript into a better book than it would otherwise have been. I would like to single out Hans-Henrik Holm, Jürgen Rüland, Thomas Hansen, Staffan Zetterholm, Pranab Bardhan, Gerd Junne, Jørgen Dige Pedersen, Alex Fernandez, Laurids Lauridsen, Ulrik Sparre, Hans Gullestrup, Margrethe Andersen and Jacques Hersh. Finally, Ellen Nyrup Pedersen did an excellent job in typing my many pages of old-fashioned, non-computerised manuscript into something more readable. The remaining shortcomings are all mine.

I would like to dedicate this book to Dieter Senghaas. Dieter has not been directly involved in the present study, but his effort over many years to find answers to the most important, 'big' questions in both development and international studies has been a constant inspiration in my own work. To shed some theoretically informed light on large topics without wandering into pure speculation with no foundation in empirical reality is the example set by the work of Dieter Senghaas. It is this ideal that the present study attempts to meet. 